\title{
A literature review of the epidemiology of sepsis in Latin America
}

\author{
Fabián Jaimes $^{1}$
}

Suggested citation

Jaimes F. A literature review of the epidemiology of sepsis in Latin America. Rev Panam Salud Publica. 2005;18(3):163-71.

ABSTRACT Objectives. Epidemiological studies from the United States of America and from Europe have shown that sepsis is a widely prevalent syndrome, with either steady or slightly decreasing rates of morbidity and of mortality in recent decades. The objective of this paper is to provide a systematic review regarding the description and characterization of sepsis in Latin America.

Methods. To locate materials on sepsis in Latin America, a comprehensive search strategy was employed with three medical bibliographic databases, using combinations of the terms "sepsis," "septicemia," "bacteremia," "sepsis syndrome," "epidemiology," "incidence," and "prevalence." The materials selected were in English, Spanish, or Portuguese.

Results. The titles of more than 1000 potentially relevant articles were screened, and more than 600 selected abstracts were reviewed in detail. Twenty papers published from 1990 through 2004 were selected and analyzed. The studies described in the 20 articles were extremely heterogeneous in design, population, sample size, end points, and follow-up. The studies did not all apply the same clinical definition for sepsis, thus making it impossible to produce a precise overall estimate of the magnitude of the problem of sepsis in Latin America.

Conclusions. The results of the literature review suggest that the clinical and epidemiological approaches to the problem of sepsis in Latin America have sometimes been inappropriate with respect to research design, study population, and clinical outcome. Further, some data suggest that in terms of both frequency and mortality the situation with sepsis and severe systemic infections may be worse in Latin America than it is in developed countries.

Key words Sepsis, hospital mortality, intensive care units, Latin America.

At the congress of the European Society of Intensive Care Medicine held in Barcelona, Spain, in October 2002,

\footnotetext{
1 Universidad de Antioquia, Medellín, Antioquia, Colombia, and Johns Hopkins Bloomberg School of Public Health, Department of Epidemiology, Baltimore, Maryland, Unites States of America. Send correspondence to: Fabián Jaimes, Universidad de Antioquia, Departamento de Medicina Interna, AA 1226, Medellín, Antioquia, Colombia; e-mail: fjaimes@catios.udea.edu.co and fjaimesb@ jhsph.edu; telephone and fax: 574-2637947.
}

the Surviving Sepsis Campaign issued the "Barcelona Declaration," a call for global action against sepsis. The Campaign, a collaborative effort of the European Society of Intensive Care Medicine, the Society of Critical Care Medicine, and the International Sepsis Forum, estimates that the number of sepsis cases in the world has reached 18 million annually. With a mortality rate of almost $30 \%$, sepsis is considered a leading cause of death world- wide (1). As such, any effort made toward improving prevention, diagnosis, and treatment represents a potentially valuable response to an urgent need.

This paper provides an overview of the global challenges with sepsis, gives a clinical definition of sepsis, and describes the magnitude of the problem in North America and Europe. In addition, a systematic review of the scientific literature describes and charac- 
terizes the situation with sepsis in Latin America.

\section{Definition of sepsis}

Over the last three decades the syndrome now commonly referred to as sepsis has alternately been called septicemia (2), sepsis syndrome (3), and simply sepsis. One definition of sepsis was described jointly with the closely related concept of systemic inflammatory response syndrome (SIRS) (4). SIRS is considered present when patients show more than one of the following four clinical characteristics: (1) body temperature $>38^{\circ} \mathrm{C}$ or $<36{ }^{\circ} \mathrm{C}$; (2) heart rate $>90$ beats / $\mathrm{min}$; (3) hyperventilation, evidenced by a respiratory rate $>20$ breaths $/$ min or $\mathrm{PaCO}_{2}<32$ mmHg; and (4) white blood cell count $>12000$ cells $/ \mu \mathrm{L}$ or $<4000$ cells $/ \mu \mathrm{L}$ or with $>10 \%$ immature forms.

A statement from a 1991 consensus conference of the American College of Chest Physicians and the Society of Critical Care Medicine hypothesized that sepsis is a systemic response to infection (4). Infection, in turn, was defined as a process whereby pathogenic or potentially pathogenic microorganisms invade normally sterile tissues, fluids, or body cavities. According to this definition, a diagnosis of sepsis requires the presence of both infection (usually caused by bacteria) and SIRS. Following the same model, sepsis with signs of organ dysfunction would be characterized as severe sepsis, and sepsis with acute circulatory failure would be defined as septic shock (4).

However, as various reports (5-7) have indicated, despite the fact that the SIRS definition states that a systemic inflammatory response can be triggered by a variety of conditions, this combination of criteria is neither specific nor sufficiently sensitive to be useful in clinical practice. It now seems clear that even though no epidemiological evidence exists to support a change in the syndrome's definition, the list of signs and symptoms of sepsis should be expanded to reflect clinical bedside experience. According to the last International Sepsis Defini-

TABLE 1. Potential sepsis-related markers

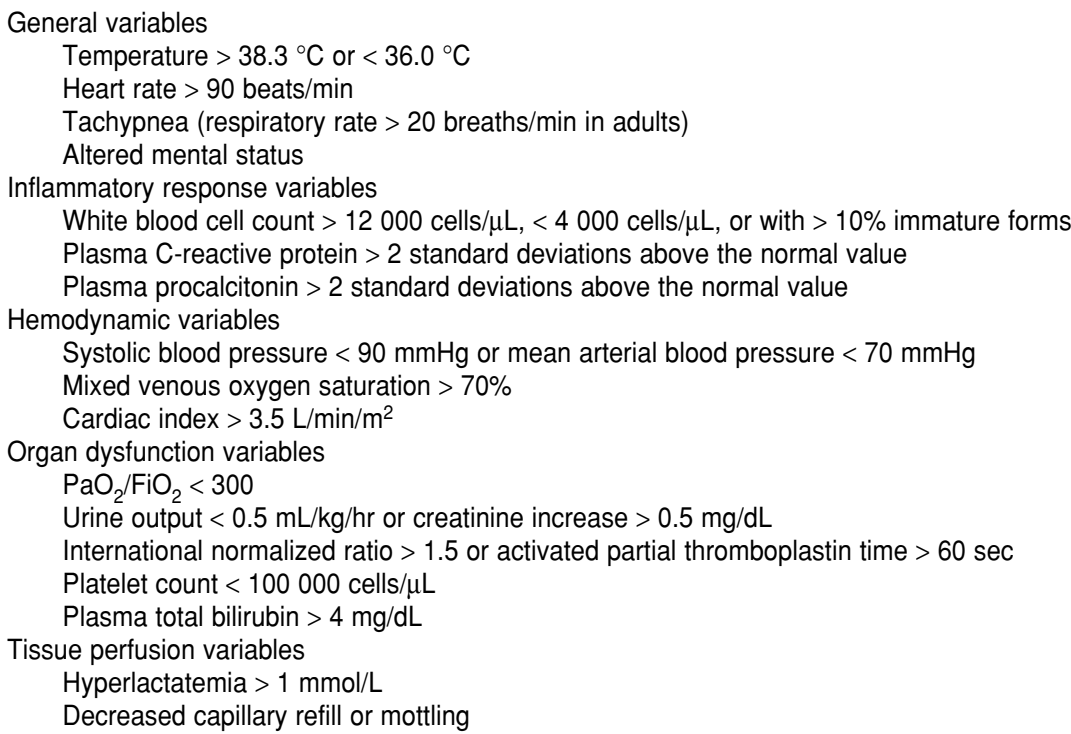

Source: Levy et al. (8), with modifications.

tions Conference, which was held in 2001, a diagnosis of sepsis should be considered in the presence of a documented or suspected infection concurrent with markers of general illness, inflammation, hemodynamic disturbance, organ dysfunction, or tissue perfusion abnormalities (Table 1) (8).

Notwithstanding the lack of conclusive criteria for sepsis, the definitions of severe sepsis (sepsis complicated by organ dysfunction) and septic shock (systolic blood pressure below 90 $\mathrm{mmHg}$, or a reduction of $>40 \mathrm{mmHg}$ from baseline despite adequate volume resuscitation) remain undisputed. In fact, most studies concerning the epidemiology of sepsis, as well as virtually all recent clinical trials for new therapies, have focused on these two study populations. Unfortunately, this simple classification and range of definitions have strong limitations for precise characterization of sepsis, and mainly for the early staging of patients. Therefore, on the basis of ideas that arose in October 2000 at the Fifth Toronto Sepsis Roundtable (9), the 2001 International Sepsis Definitions Conference proposed a classification scheme called "PIRO" (8). The PIRO staging system proposes to stratify patients based on their predisposition (P), the type and extent of the infection (I), the nature and magnitude of the host response (R), and the degree of associated organ dysfunction (O). However, comprehensive evaluation and further improvements on the PIRO approach are needed.

\section{The magnitude of the sepsis problem in the United States}

The first relevant general public disclosure of the magnitude of the sepsis problem in United States came from the Centers for Disease Control and Prevention (CDC) in 1990, in a comparison of hospital discharge rates for septicemia from 1979 through 1987 (10). The data were obtained from the National Hospital Discharge Survey of the CDC's National Center for Health Statistics. The report used the discharge diagnosis of septicemia ("systemic disease associated with the presence and persistence of pathogenic microorganisms or their toxins in the blood") of the International Classification of Diseases, Ninth Revision, Clin- 
ical Modification (ICD-9-CM). The analysis covered all records of persons one year old or older in which a discharge diagnosis of septicemia was recorded from 1979 through 1987. During this period, septicemia rates increased $139 \%$, from 73.6 per 100000 persons (164000 discharges) to 175.9 per 100000 persons (425000 discharges). Although the septicemia rate increased for all age groups, the increase was greatest (162\%) for persons aged 65 years or older, from 326.3 per 100000 in 1979 to 854.7 per 100000 by 1987. The fatality rate for patients with a discharge diagnosis of septicemia declined during the study period for all age groups, from $31.0 \%$ to $25.3 \%$. However, even by 1987, patients were at significantly greater risk of death if septicemia was one of the discharge diagnoses (relative risk $=8.6$; $95 \%$ confidence interval = 8.14-9.09) (10).

The most comprehensive study on the clinical significance of the early stages of septic syndrome appeared in 1995 (11). The study assessed the incidence of SIRS, sepsis, severe sepsis, and septic shock among 3708 patients admitted during a nine-month period to three intensive care units (ICUs) and three wards of a 900-bed teaching hospital in the state of Iowa, in the United States. The study found that $68 \%$ of the patients met at least two criteria for SIRS at some point during their hospital stay. Of those patients with SIRS, $26 \%$ developed microbiologically confirmed sepsis, $18 \%$ developed severe sepsis, and $4 \%$ developed septic shock. Positive blood cultures were found in $16.5 \%, 25.4 \%$, and $69.0 \%$ of the samples drawn from patients with sepsis, severe sepsis, and septic shock, respectively. A noteworthy finding was that fewer than $50 \%$ of the episodes overall were microbiologically documented. This proportion ranged from $42 \%$ for patients who only met the criteria for SIRS to $57 \%$ for patients with septic shock. Since clinical suspicion of infection was enough to initiate antibiotic treatment, the precise cause of the systemic inflammatory response in these culturenegative populations is unknown. However, they had morbidity and mortality rates that were similar to those of the corresponding culturepositive populations (11).

Clearly, these definitions are selfcontained, since severe sepsis includes sepsis, and, in turn, sepsis includes SIRS. Therefore, only in a tautological sense might we consider that there is a true continuum through different stages of an inflammatory response, from SIRS to septic shock. Indeed, in the same Iowa study (11), among 649 patients with sepsis, only 285 of them $(44 \%)$ had earlier met at least two criteria for SIRS. Among those who met the criteria for severe sepsis (cultureproven; $n=467), 58 \%$ of them $(n=271)$ had been previously classified as being afflicted with sepsis or SIRS. On the other hand, among those with two SIRS criteria, $32 \%$ developed sepsis by day 14, and for those with three SIRS criteria, 36\% developed sepsis by day 14 . Forty-five percent $(n=439)$ of the 975 subjects with four criteria developed sepsis between days 14 and 21 . Thus, even without a categorical progression, a close relationship clearly exists between clinical stages reflecting some degree of systemic inflammation and the presence of infection. Whether infection is confirmed or is clinically suspected, the outcomes seem similar in terms of mortality and most organ dysfunctions, within each corresponding stage.

In 1997, Sands et al. (12) evaluated the incidence of sepsis syndrome in both the ICU and ward populations at eight academic tertiary-care medical centers in the United States (12). Each center monitored a weighted random sample of ICU patients and of non-ICU patients who had blood cultures drawn during a 15-month period. Sepsis syndrome was defined as the presence of either a positive blood culture or the combination of fever, tachypnea, tachycardia, clinically suspected infection, and any one of seven confirmatory criteria, all of them related to organ dysfunction. In total, 12759 patients were monitored, and 1342 episodes of sepsis syndrome were documented. The extrapolated, weighted estimate of hospitalwide incidence (mean $\pm 95 \%$ confidence limit) of sepsis syndrome was
$2.0 \pm 0.16$ cases per 100 admissions. Among the centers the unadjusted attack rate for sepsis syndrome ranged from 1.1 to 3.3 cases per 100 admissions. Patients in ICUs accounted for $59 \%$ of total extrapolated cases, nonICU patients with positive blood cultures for $11 \%$, and non-ICU patients with negative blood cultures for $30 \%$. Septic shock was present at the onset of the sepsis syndrome in $25 \%$ of patients. Bloodstream infection was documented in $28 \%$ of patients, and the total 28-day mortality was $34 \%$.

The most compelling evidence of systemic infection is bacteremia. For this reason, some evaluations of the incidence of sepsis have focused on bacteremia. Furthermore, requesting blood cultures, as in the study of Sands et al. (12) mentioned above, is considered a proxy for clinical sepsis. Although clinically appealing, this last "surrogate marker" is not reproducible enough, and it should be viewed with caution. There are patients with potential infection who may not have a blood culture performed, and other patients without infection who have cultures requested inappropriately. Furthermore, since patients with comorbidities often are suspected of being at increased risk for infection, clinicians may have a lower threshold for requesting blood cultures in these patients. Therefore, any analysis about these cases should take into account the real denominator of population at risk. Nevertheless, positive blood cultures clearly identify infected individuals at higher risk of mortality, and appropriate inferences may be derived from this population.

Despite using somewhat different definitions, two recent reports have added important information regarding the epidemiology of sepsis in the United States in the last 20 years (13, 14). Based on hospital discharge records for 1995 for seven large states in the United States, Angus et al. (13) estimated that for the United States as a whole there were 3.0 cases of severe sepsis per 1000 population, and 2.26 cases per 100 hospital discharges. Of the some 751000 severe sepsis cases in the study, almost $70 \%$ of them 
(513 000) received intensive care. The estimated mortality rate was $28.6 \%$, or a total of 215000 deaths nationally, and the average cost per case was US\$ 22 100, with a total annual cost of US\$ 16.7 billion. Using a more restrictive definition that included only a few codes from the ICD-9-CM and working with data from the National Hospital Discharge Survey, Martin et al. (14) found an increase in the incidence of sepsis, from 82.7 cases per 100000 population in 1979 to 240.4 per 100000 population in 2000. This represents an annualized increase of $8.7 \%$ in the incidence. The authors also described a decline in the overall in-hospital mortality rate, from $27.8 \%$ during the 1979-1984 period to $17.9 \%$ during the 1995-2000 period, even though the total number of deaths continued to increase.

The results from Angus et al. (13), Martin et al. (14), and the CDC (10) may be limited by the quality of the state and National Hospital Discharge Survey databases, and by the inability to audit their data. Moreover, the accuracy of the ICD-9-CM coding for the identification of specific medical conditions, and sepsis in particular, remains controversial (15). Administrative data sets have become essential resources for epidemiological investigations in which the prospective identification of patients is difficult or not feasible. However, strict reliance on such data sets for sepsis surveillance or research planning may produce substantial error.

\section{The magnitude of the sepsis problem in Europe}

In Europe the first hospitalwide epidemiologic study on bacteremia and sepsis was a French multicenter one, conducted in 1993 in 24 public or public-affiliated hospitals $(16,17)$. The authors performed a two-month prospective survey of 85750 admissions to adult wards and ICUs, and they found an overall incidence rate of bacteremia of 9.8 per 1000 admissions (16). The bacteremia incidence rate in the ICUs (69/1000) was more than eight times as high as the rate in the wards (8.2/1 000) (17). Of the 842 bacteremic episodes detected, $63 \%$ occurred in medical wards, $19 \%$ in ICUs, and $18 \%$ in surgical wards (16). Extrapolating these results to all of France would give a figure of approximately 67500 bacteremic episodes per year $(17,18)$. Of note, nearly half of the bacteremic episodes were of nosocomial origin (16). Although ICU patients were at much higher risk of severe sepsis than were ward patients, bacteremic severe sepsis was proportionally less often encountered in ICU patients than in non-ICU patients (16, 17). This suggests that there is an important subset of patients who have overwhelming infections, besides the patients in ICUs, which traditionally have been considered the natural setting for sepsis (19).

Despite the broad distribution of sepsis and severe bacterial infections among hospitalized patients, all the recent studies outside the United States have only considered patients admitted to ICUs (20-24). Whether on prospective cohorts $(20,23,24)$ or with administrative databases $(21,22)$, all of the studies but one (20) have focused on severe sepsis or septic shock (Table 2.).

The wide range of incidence and mortality rates found in the studies mentioned above reflects different definitions of outcome measures as well as differences in data collection procedures or methodological approaches. Three of these studies provide some understanding of time trends (21-23).

TABLE 2. Studies on the epidemiology of sepsis in various countries around the world

\begin{tabular}{|c|c|c|c|c|c|c|}
\hline $\begin{array}{l}\text { Author, year } \\
\text { (reference) }\end{array}$ & Countries & Design & $\begin{array}{c}\text { Number of } \\
\text { intensive care } \\
\text { unit (ICU) } \\
\text { admissions } \\
\text { screened }\end{array}$ & Outcome & $\begin{array}{c}\text { Relative } \\
\text { frequency } \\
(\%)\end{array}$ & $\begin{array}{l}\text { Mortality } \\
(\%)\end{array}$ \\
\hline Alberti, 2002 (20) & $\begin{array}{c}\text { Six European } \\
\text { countries, } \\
\text { Canada, and } \\
\text { Israel }\end{array}$ & $\begin{array}{l}\text { Prospective cohort } \\
\text { study }\end{array}$ & 14364 & Infectious episodes & 21.1 & $\begin{array}{c}22.1 \text { vs. } 43.6 \\
\text { (community- vs. } \\
\text { hospital-acquired } \\
\text { infection) }\end{array}$ \\
\hline Padkin, 2003 (21) & $\begin{array}{l}\text { England, Wales, } \\
\text { and Northern } \\
\text { Ireland }\end{array}$ & $\begin{array}{c}\text { Administrative } \\
\text { database }\end{array}$ & 56673 & Severe sepsis & 27.1 & $\begin{array}{l}35 \text { vs. } 47 \text { (ICU vs. } \\
\text { hospital mortality) }\end{array}$ \\
\hline Annane, 2003 (22) & France & $\begin{array}{c}\text { Administrative } \\
\text { database }\end{array}$ & 100554 & Septic shock & 8.2 & 60.1 \\
\hline EPISEPSIS, 2004 (23) & France & $\begin{array}{l}\text { Prospective cohort } \\
\text { study }\end{array}$ & 3738 & $\begin{array}{l}\text { Severe sepsis or } \\
\text { septic shock }\end{array}$ & 14.6 & $\begin{array}{c}35 \text { vs. } 41.9 \text { (30-day vs. } \\
\text { 2-month mortality) }\end{array}$ \\
\hline Finfer, 2004 (24) & $\begin{array}{l}\text { Australia and } \\
\text { New Zealand }\end{array}$ & $\begin{array}{l}\text { Prospective cohort } \\
\text { study }\end{array}$ & 5878 & Severe sepsis & 11.8 & $\begin{array}{c}26.5 \text { vs. } 32.4 \text { (ICU vs. } \\
28 \text {-day mortality) }\end{array}$ \\
\hline
\end{tabular}


Padkin et al. (21) assessed data for 1995 through 2000 from 91 adult general ICUs in England, Wales, and Northern Ireland. The relative frequency of severe sepsis for all ICU admissions increased from $25.9 \%$ in 1996 to $29.7 \%$ in 1999. In the same period there was a slight decrease in the hospital mortality rate, from $50.2 \%$ to $47.0 \%$. The database of the CUB-Réa Network has information from 35 ICUs in Paris and its suburbs (22). An analysis of the data for 1993 through 2000 showed that the overall frequency of septic shock increased from 7.0 to 9.7 per 100 admissions, while the crude mortality rate declined from $62.1 \%$ to $55.9 \%$ over that same period. Similarly, the EPISEPSIS Study Group (23) compared findings for 2001 with studies performed in 1993 in France by some of the same researchers $(16,17)$. They found that there was an increase in the attack rate of severe sepsis in ICU patients between 1993 and 2001, from 8.4\% to $14.6 \%$ for clinically severe sepsis, and from $6.3 \%$ to $9.0 \%$ for microbiologically documented severe sepsis. The $42 \%$ hospital mortality rate found for 2001 (23) was substantially lower than the $59 \%$ rate in $1993(16,17)$.

From the information presented above, it is clear that sepsis is a common and frequently fatal condition in developed countries. Dealing with it involves spending considerable funds and other resources. While the overall mortality rate among patients with sepsis is declining, the incidence and the number of sepsis-related deaths have increased substantially over the past two decades.

Developing countries are different from developed nations in many ways. For example, Latin American countries differ substantially from the United States and from European nations in terms of ethnic background, cultural heritage, health services, and clinical research. These differences highlight the importance of exploring sepsis in Latin America from an epidemiological and clinical point of view. The objective of the rest of this paper is to provide a systematic review of the situation surrounding sepsis in Latin America.

\section{MATERIAL AND METHODS}

To begin the review of the sepsis situation in Latin America, the first step was to search bibliographic databases for possibly relevant articles. Three databases were used: PubMed (National Library of Medicine of the United States), EMBASE (Excerpta Medica (http:// www.embase.com)), and LILACS ( $\mathrm{Li}$ teratura Latino-Americana e do Caribe em Ciências da Saúde, of the Latin American and Caribbean Center on Health Sciences Information, in São Paulo, Brazil (http://www.bireme.br)). Different combinations with the search terms "sepsis," "septicemia," "bacteremia," "sepsis syndrome," "epidemiology," "incidence," and "prevalence" were employed. For PubMed and EMBASE, the search strategy additionally included the terms "Latin America," "South America," and "Central America," or restriction to items in Spanish or Portuguese. The database searching produced more than 1000 potentially related articles, most of them from LILACS. The next stage of the screening involved a detailed review of more than 600 selected abstracts. Articles were retained based on their appropriateness and relevance, with no restrictions on design, sample size, year(s) in which the study was done, year of publication, or journal that published the study.

\section{RESULTS AND DISCUSSION}

The process of searching the databases, locating relevant titles, and screening the abstracts yielded 20 articles, which had been published between 1990 and 2004 (5, 25-43). There was a noticeably large number of highquality papers regarding neonatal sepsis and severe infections in pediatric populations in Latin America. For adult patients, however, the number and scope of the investigations was more limited. Additionally, for one article only the abstract could be obtained (25), and 7 out of the remaining 19 articles $(26,28,29,34,38,40,41)$ analyzed sepsis as a secondary outcome from a wide definition of nosocomial infections (Table 3).
The studies described in the 20 selected articles were extremely heterogeneous in design, population, sample size, end points, and follow-up. Furthermore, the fundamental challenge of lack of consensus on the clinical definition of sepsis seems to be more critical in Latin American literature. Therefore, it is impossible to infer any overall estimate of the magnitude of the problem in Latin America. Moreover, some data suggest that in terms of frequency and mortality, the situation with sepsis and severe systemic infections in Latin America may be even worse than in developed countries.

In an article published in 1990, Zanon et al. (25) used ICD-9-CM codes for septicemia at 10 hospitals in Brazil and estimated a mortality rate of $46 \%$ for community-acquired sepsis and of $58 \%$ for nosocomially acquired sepsis. In spite of potential underreporting, the incidence of bacteremia in these hospitals was roughly similar to estimates for France (16). Studies performed in ICUs (27, 30, 33, 34, 39) between 1993 and 2001 found mortality rates ranging from $33.6 \%$ in a cross-sectional study by Ponce de León-Rosales et al. in Mexico (34) to $56 \%$ in a retrospective caseseries by Bilevicius et al. in Brazil (39). These figures are roughly similar to those reported for ICUs elsewhere around the world. However, all the Latin American studies but one (33) recruited a general population of sepsis patients, without restrictions as to organ dysfunction (i.e., severe sepsis) or septic shock. These patients with severe sepsis and/or septic shock have been the usual study populations for sepsis in developed nations (13, 22-24). Therefore, a much higher mortality rate for the subset of those with severe sepsis is expected in Latin American countries. Two prospective cohort studies from Colombia $(5,35)$, in infected patients admitted to the emergency room with SIRS criteria, found a mortality rate ranging from $24 \%$ (35) to $31 \%$ (5), which increased to $40 \%$ for patients in the ICU or with a positive blood culture (36). Assuming these cohorts correspond to a "less ill" population, the mortality rates are similar to the global estimates for sepsis. 
TABLE 3. Research on sepsis in Latin America

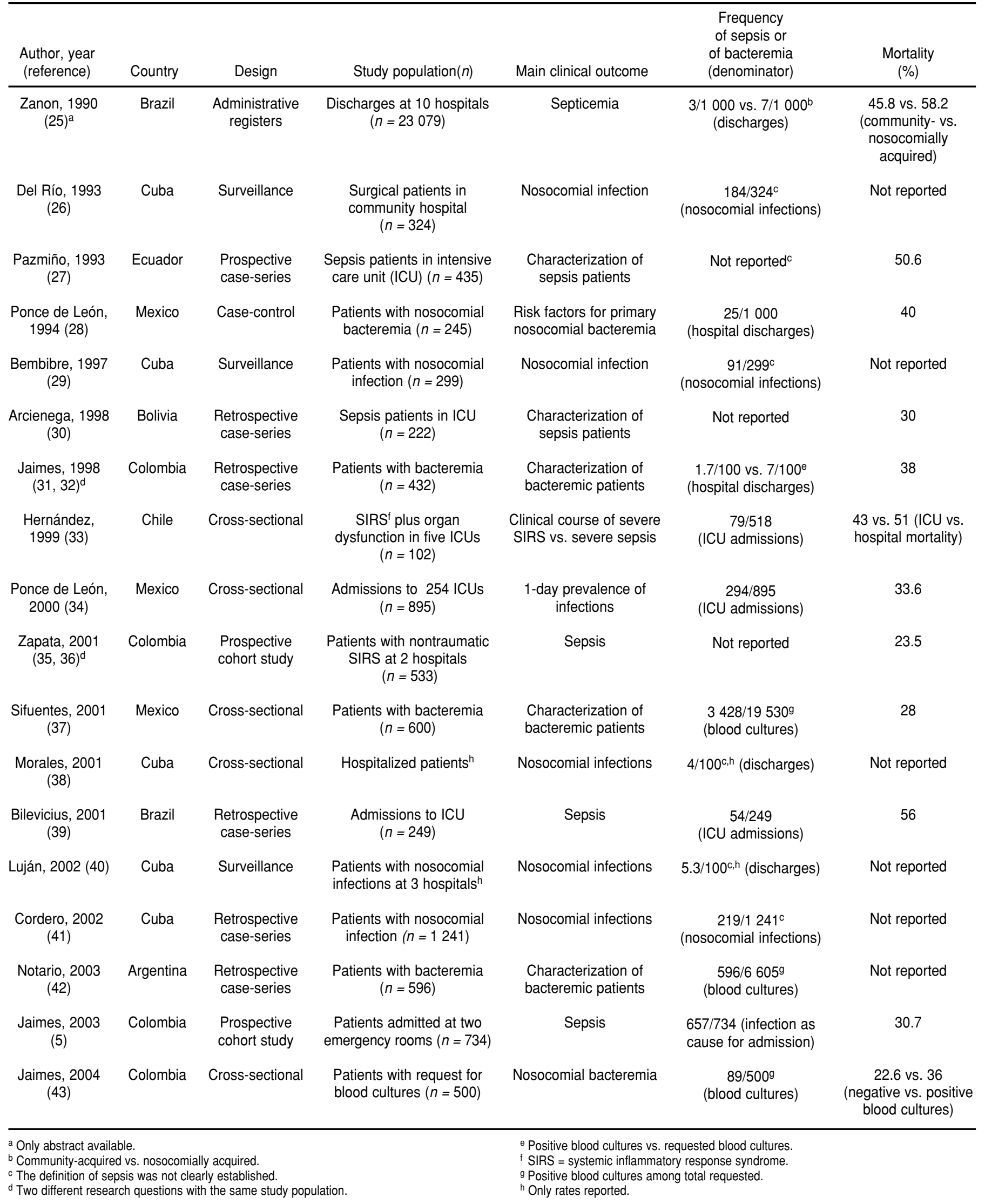


For a tertiary center in Mexico in 1989, Ponce de León et al. (28) found a rate of nosocomial bacteremia without an identified source (designated "primary bacteremia") of 25/1000 discharges, with a mortality rate of $40 \%$. This subset of primary bacteremia may represent less than $20 \%$ of the total affected population with bacteremia and/or sepsis $(44,45)$; hence, the real estimate for bacteremia or sepsis should be more than 100 cases per 1000 discharges for this hospital. Jaimes et al. $(31,32)$ estimated that severe infections and/or bacteremia were the main causes for emergency admission in 7 out of 100 patients at a university hospital in Colombia. Similarly, in the same hospital, blood cultures were requested in 2 out of 10 in-patients at some time during their hospitalization $(32,43)$.

Working with data from a referral center in Mexico, Sifuentes-Osornio et al. (37) developed the only study that gives some information on time trends. Those authors found an overall frequency of bacteremia of $18 \%$ among patients from whom a blood culture was requested. The crude mortality rate was $70 \%$ for nosocomially acquired bacteremia, and 30\% for community-acquired bacteremia. The authors analyzed randomly selected samples of positive blood cultures for three different periods: from 1981 to 1984, from 1985 to 1988, and from 1989 to 1992. Surprisingly, the overall mortality rate showed a modest decrease for the three study periods, with it being $29.5 \%, 27.5 \%$, and $27.0 \%$, respectively. The authors pointed out that the mortality rate also remained almost the same whether the bacteremia was community-acquired or nosocomially acquired. Their findings contrast with the description of decreasing trends of mortality in the United States and Europe over the last two decades (14, 21-23).

An additional concern with the published literature on sepsis in Latin America is that only the study by Hernández et al. (33) had an average patient age higher than 50 years; that study had a population with a mean age of 61 years and a range of 18 to 87 years. All of the other study populations, whether in ICUs, general wards, or emergency rooms, had mean ages of 50 years or below. This contrasts sharply with the studies done in Europe and the United States, in which the mean age was 60 years or above $(13,14,20,22,24)$. Whatever the demographic or epidemiological explanation, it seems that Latin America doctors and health care systems are facing sepsis in a younger and probably "healthier" population, but with morbidity and mortality rates at least as high as those from developed countries.

Finally, in a cross-sectional study of 254 multidisciplinary ICUs throughout Mexico in 1995, Ponce de LeónRosales et al. (34) found a one-day point prevalence of $16 \%$ for sepsis and of $17 \%$ for severe sepsis or septic shock. For sepsis and other diseases with short duration and early mortality, prevalence studies may underestimate their frequency, and the studies do not provide a true estimate of risk.
Even so, these one-day point prevalence figures in Mexico are higher than those in corresponding prospective cohort studies performed in ICUs in Europe and Australia $(23,24,46)$.

In summary, sepsis is a problem around the world, and the problem is growing. It produces a high burden of mortality and morbidity, and it consumes large amounts of resources. The results of this study suggest that in Latin America the clinical and epidemiological approaches to the problem have sometimes been inappropriate in terms of research design, study population, and clinical outcome. It is unlikely that in Latin America there is a lower incidence of sepsis or a better prognosis for the condition than there is in the developed countries of the world. Instead, it seems that the first two points of the action plan stated by the "Barcelona Declaration" (1) are especially needed in the countries of Latin America: (1) "Increase awareness of health care professionals, governments, health and funding agencies, and the public of the high frequency and mortality associated with sepsis" and (2) "Improve the early and accurate diagnosis of sepsis by developing a clear and clinically relevant definition of sepsis and disseminating it to our peers."

Acknowledgements. I am indebted to Mónica Pineda and Diana Chalarca (Biblioteca Médica, Universidad de Antioquia) for technical and bibliographic support. I appreciate the helpful suggestions from Luis Gabriel Cuervo and the three anonymous referees.

\section{REFERENCES}

1. Slade E, Tamber PS, Vincent JL. The Surviving Sepsis Campaign: raising awareness to reduce mortality. Crit Care. 2003;7(1):1-2.

2. Pierce G, Murray PR. Current controversies in the detection of septicemia. Eur J Clin Microbiol. 1986;5:487-91.

3. Bone RC, Fisher CJ Jr, Clemmer TP, Slotman GJ, Metz CA, Balk RA. Sepsis syndrome: a valid clinical entity. Methylprednisolone Severe Sepsis Study Group. Crit Care Med. 1989;5:389-93.
4. American College of Chest Physicians/ Society of Critical Care Medicine Consensus Conference. Definitions for sepsis and organ failure and guidelines for the use of innovative therapies in sepsis. Crit Care Med. 1992; 20:864-74.

5. Jaimes F, Garcés J, Cuervo J, Ramírez F, Ramírez J, Vargas A, et al. The systemic inflammatory response syndrome (SIRS) to identify infected patients in the emergency room. Intensive Care Med. 2003;29:1368-71.
6. Vincent J-L. Dear SIRS, I'm sorry to say that I don't like you. Crit Care Med. 1997;25: 372-4.

7. Marshall JC. SIRS and MODS: What is their relevance to the science and practice of intensive care? Shock. 2000;14:586-9.

8. Levy MM, Fink MP, Marshall JC, Abraham E, Angus D, Cook D, et al. 2001 SCCM/ESICM/ ACCP/ATS/SIS International Sepsis Definitions Conference. Crit Care Med. 2003;31: 1250-6. 
9. Marshall JC, Vincent J-L, Fink MP, Cook D, Rubenfeld G, Foster D, et al. Measures, markers, and mediators: toward a staging system for clinical sepsis. A report of the Fifth Toronto Sepsis Roundtable, Toronto, Ontario, Canada, October 25-26, 2000. Crit Care Med. 2003;31:1560-7.

10. United States of America, Centers for Disease Control and Prevention. Increase in National Hospital Discharge Survey rates for septicemia-United States, 1979-1987. MMWR. 1990;39(2):31-4.

11. Rangel-Frausto $S$, Pittet D, Costigan M, Hwang T, Davis CS, Wenzel RP. The natural history of the systemic inflammatory response syndrome. JAMA. 1995;273:117-23.

12. Sands KE, Bates DW, Lanken PN, Graman PS, Hibberd PL, Kahn KL, et al. Epidemiology of sepsis syndrome in 8 academic medical centers. Academic Medical Center Consortium Sepsis Project Working Group. JAMA. 1997; 278(3):234-40.

13. Angus DC, Linde-Zwirble WT, Lidicker J, Clermont G, Carcillo J, Pinsky MR. Epidemiology of severe sepsis in the United States: analysis of incidence, outcome, and associated costs of care. Crit Care Med. 2001;29: 1303-10.

14. Martin GS, Mannino DM, Eaton S, Moss M. The epidemiology of sepsis in the United Sates from 1979 through 2000. N Engl J Med. 2003;348:1546-54.

15. Ollendorf DA, Fendrick AM, Massey K, Williams GR, Oster G. Is sepsis accurately coded on hospital bills? Value Health. 2002; 5(2):79-81.

16. Brun-Buisson C, Doyon F, Carlet J. Bacteremia and severe sepsis in adults: a multicenter prospective survey in ICUs and wards of 24 hospitals. French Bacteremia-Sepsis Study Group. Am J Respir Crit Care Med. 1996; 154(3):617-24.

17. Brun-Buisson C, Doyon F, Carlet J, Dellamonica P, Gouin F, Lepoutre A, et al. Incidence, risk factors, and outcome of severe sepsis and septic shock in adults. A multicenter prospective study in intensive care units. French ICU Group for Severe Sepsis. JAMA. 1995;274(12): 968-74.

18. Brun-Buisson C. The epidemiology of the systemic inflammatory response. Intensive Care Med. 2000;26 Suppl 1:S64-74.

19. Moss M, Martin GS. A global perspective on the epidemiology of sepsis. Intensive Care Med. 2004;30(4):527-9.

20. Alberti C, Brun-Buisson C, Burchardi H, Martin C, Goodman S, Artigas A, et al. Epidemiology of sepsis and infection in ICU patients from an international multicentre cohort study. Intensive Care Med. 2002;28(2):108-21.

21. Padkin A, Goldfrad C, Brady AR, Young D, Black N, Rowan K. Epidemiology of severe sepsis occurring in the first $24 \mathrm{hrs}$ in intensive care units in England, Wales, and Northern Ireland. Crit Care Med. 2003;31(9):2332-8.

22. Annane D, Aegerter P, Jars-Guincestre MC, Guidet B. Current epidemiology of septic shock: the CUB-Réa Network. Am J Respir Crit Care Med. 2003;168(2):165-72.

23. The EPISEPSIS Study Group. EPISEPSIS: a reappraisal of the epidemiology and outcome of severe sepsis in French intensive care units. Intensive Care Med. 2004;30(4):580-8.

24. Finfer S, Bellomo R, Lipman J, French C, Dobb $\mathrm{G}$, Myburgh J. Adult-population incidence of severe sepsis in Australian and New Zealand intensive care units. Intensive Care Med. 2004;30(4):589-96.

25. Zanon U, Pereira L de O, Kelm LS, Gonçalves AJ. Septicemia: incidência, mortalidade, letalidade e condições predisponentes em 10 hospitais brasileiros e 23,079 pacientes. Rev Med St Casa. 1990;2(3):213-8.

26. Del Río J, Hernández JM, Peón A, Suárez M. Infección nosocomial. Estudio de 2 años. Rev Cubana Cir. 1993;32(1):14-23.

27. Pazmiño L, Cifuentes A. Estudio epidemiológico de 435 pacientes sépticos en una unidad de cuidados intensivos general. Rev Hosp Eugenio Espejo. 1993;3(1):1-13.

28. Ponce de León S, Rivera I, Romero C, Ortiz R, Sánchez-Mejorada G. Factores de riesgo para bacteremias primarias: un estudio de casos y controles. Gac Med Mex. 1994;130(5):368-72.

29. Bembibre R, González E, Quintero C. Sepsis nosocomial. Rev Cubana Med. 1997;36(2) 95-9.

30. Arcienega TL, Barrón M. Características de infecciones en unidades de terápia intenciva [sic]. Experiencia durante periodo de diez años. Archiv Boliv Med. 1998;5(58):25-30.

31. Jaimes F, Valencia M, Vélez L. Significado clínico de los hemocultivos. Una cohorte retrospectiva en el Hospital San Vicente de Paul. Infectio. 1998;2(2):69-76.

32. Jaimes F, Martínez CE, Valencia M, Rosso F. Predicción de mortalidad en pacientes con bacteremia y sepsis. Acta Med Colomb. 1999; 24(3):96-101.

33. Hernández G, Dougnac A, Castro J, Labarca G, Ojeda M, Bugedo G, et al. Síndrome de respuesta inflamatoria sistémica: es comparable a la sepsis severa? Rev Med Chil. 1999;127 (11):1339-44.

34. Ponce de León-Rosales SP, Molinar-Ramos F, Domínguez-Cherit G, Rangel-Frausto MS
Vázquez-Ramos VG. Prevalence of infections in intensive care units in Mexico: a multicenter study. Crit Care Med. 2000;28(5):1316-21.

35. Jaimes F, Garcés I, Cuervo I, Ramírez I, Ramírez F, Estrada JC, et al. Factores pronósticos en el síndrome de respuesta inflamatoria sistémica (SRIS). Desarrollo de un índice de severidad. Acta Med Colomb. 2001;26(4): 149-57.

36. Zapata L, Jaimes F, Garcés J, Leal H, Yepes $\mathrm{MM}$, Cuervo J, et al. Descripción de una cohorte de pacientes con criterios de síndrome de respuesta inflamatoria sistémica en dos hospitales de tercer nivel. Iatreia. 2001;14(1): 26-34.

37. Sifuentes-Osornio J, Guerrero-Almeida MC, Ponce de León-Garduño LA, GuerreroAlmeida ML. Tendencias de las bacteremias y factores de riesgo para muerte en un hospital terciario de la ciudad de México. 1981-1992. Gac Med Mex. 2001;137(3):191-202.

38. Morales C, Fresneda G, Guanche H. Prevalencia puntual de infección nosocomial. Rev Cubana Enferm. 2001;17(2):84-9.

39. Bilevicius E, Dragosavac D, Dragosavac S, Araújo S, Falcão AL, Terzi RG. Multiple organ failure in septic patients. Braz J Infect Dis 2001;5(3):103-10.

40. Luján M. Tendencias y pronósticos de las infecciones nosocomiales en la provincia de Cienfuegos. Rev Cubana Hig Epidemiol. 2002; 40(1):20-5

41. Cordero DM, García AL, Barreal RT, Jiménez J, Rojas N. Comportamiento de la infección nosocomial en las unidades de terapia en un periodo de 5 años. Rev Cubana Hig Epidemiol. 2002;40(2):79-88.

42. Notario R, Borda N, Gambande T, Sutich E. Bacteremia en dos hospitales de Rosario Argentina. Rev Argent Microbiol. 2003;35(3): 167-70.

43. Jaimes F, Arango C, Ruiz G, Cuervo J, Botero J, Vélez G, et al. Predicting bacteremia at the bedside. Clin Infect Dis. 2004;38(3):357-62.

44. Wenzel RP. Treating sepsis. N Engl J Med. 2002;347:966-7.

45. Angus DC, Wax RS. Epidemiology of sepsis: an update. Crit Care Med. 2001;29:S109-S116.

46. Alberti C, Brun-Buisson C, Goodman SV, Guidici D, Granton J, Moreno R, et al. Influence of systemic inflammatory response syndrome and sepsis on outcome of critically ill infected patients. Am J Respir Crit Care Med. 2003;168(1):77-84.

Manuscript received 13 October 2004. Revised version accepted for publication 22 April 2005. 
RESUMEN Objetivos. Algunos estudios epidemiológicos realizados en Estados Unidos de América y en Europa han demostrado que la septicemia es un síndrome de muy amplia distribución cuya frecuencia ha permanecido estable o ha descendido ligeramente en los últimos decenios. El presente trabajo tiene por objetivo presentar los resultados de una revisión bibliográfica sistemática a fin de describir y caracterizar el problema de la septicemia en América Latina.

Métodos. Para localizar materiales sobre el tema de la septicemia en América Latina, se efectuó una búsqueda global en tres bases de datos médicas usando los términos "sepsis", "septicemia", "bacteremia", "sepsis syndrome", "epidemiology", "incidence" y "prevalence". Se abarcaron materiales en inglés, español y portugués.

Resultados. Se examinaron los títulos de más de 1000 artículos de posible interés, y se revisaron detenidamente los resúmenes de más de 600 de ellos. En total se escogieron y analizaron 20 trabajos publicados entre 1990 y 2004 con gran heterogeneidad en cuanto a diseño, población, tamaño muestral, criterios de valoración y seguimiento. No en todos se aplicó la misma definición clínica de septicemia, lo cual impidió calcular con precisión la magnitud general del problema de la septicemia en América Latina. Conclusiones. Según los resultados de la revisión bibliográfica, algunos estudios de carácter clínico u epidemiológico efectuados en América Latina en torno a la septicemia han sido deficientes en cuanto a diseño, población estudiada y resultado clínico evaluado. Además, hay datos que apuntan a que la septicemia y las infecciones generalizadas graves podrían ser más frecuentes y acarrear mayor mortalidad en países de América Latina que en países desarrollados.

Palabras clave Sepsis, mortalidad hospitalaria, unidades de terapia intensiva, América Latina.

\section{ERRATUM}

Ferrero $\mathrm{F}$ et al. Prevalencia del consumo de tabaco en médicos residentes de pediatría en Argentina. (Rev Panam Salud Publica/Pan Am J Public Health 2004;15(6):395-99).

La redacción llama la atención de los lectores a un error en la versión publicada del artículo señalado.

P. 395, tercera línea de la tercera nota al pie de página: Versión equivocada: "Verónica Rodríguez". Versión correcta: "Viviana Rodríguez". 